\title{
HPV-negative squamous cell carcinoma of the anal canal is unresponsive to standard treatment and frequently carries disruptive mutations in TP53
}

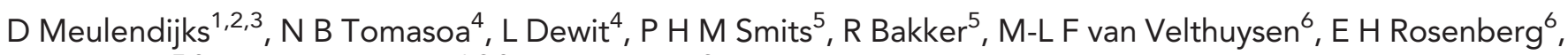
J H Beijnen ${ }^{7,8}$, J H M Schellens ${ }^{1,2,8}$ and A Cats ${ }^{\star, 3}$

${ }^{1}$ Division of Clinical Pharmacology, Department of Medical Oncology, The Netherlands Cancer Institute, Amsterdam, The Netherlands; ${ }^{2}$ Department of Molecular Pathology, The Netherlands Cancer Institute, Amsterdam, The Netherlands; ${ }^{3}$ Division of Gastroenterology and Hepatology, Department of Medical Oncology, The Netherlands Cancer Institute, Plesmanlaan 121, Amsterdam 1066 CX, The Netherlands; ${ }^{4}$ Department of Radiation Oncology, The Netherlands Cancer Institute, Amsterdam, The Netherlands; ${ }^{5}$ Department of Molecular Biology, Slotervaart Hospital, Amsterdam, The Netherlands; ${ }^{6}$ Department of Pathology, The Netherlands Cancer Institute, Amsterdam, The Netherlands; ${ }^{7}$ Department of Pharmacy and Pharmacology, The Netherlands Cancer Institute, Amsterdam, The Netherlands and ${ }^{8}$ Faculty of Science, Division of Pharmacoepidemiology and Clinical Pharmacology, Department of Pharmaceutical Sciences, Utrecht University, Utrecht, The Netherlands

Background: Human papillomavirus (HPV), p16 expression, and TP53 mutations are known prognostic factors in head and neck squamous cell carcinoma, but their role in squamous cell carcinoma of the anal canal (SCCAC) is less well established. The objective of this study was to determine the prognostic significance of tumour HPV status, p16 and p53 expression, and mutations in TP53 in patients with SCCAC receiving (chemo)radiotherapy.

Methods: Human papillomavirus DNA was determined using an INNO-LiPA-based assay in tumour tissue of 107 patients with locally advanced SCCAC. Patients were treated with radiotherapy, with or without concurrent chemotherapy consisting of a fluoropyrimidine and mitomycin C. Expression of p16 and p53 was determined using immunohistochemistry. Exons 2-11 of TP53 in tumour tissue were sequenced.

Results: DNA of high-risk HPV types was detected in 93 out of 107 tumours (87\%), all of which overexpressed p16 (HPV + /p16 + ). Of 14 HPV-negative (HPV - ) tumours (13\%), 10 (9\%) were p16-negative (HPV - /p16 - ) and 4 (4\%) overexpressed p16 (HPV - /p16 +). Patients with HPV - /p16 - disease had inferior 3-year locoregional control (LRC) (15\%) compared with patients with HPV $+/ \mathrm{p} 16+$ tumours (82\%, $P<0.001)$ and HPV - /p16 + tumours (75\%, $P=0.078)$. Similarly, 3-year overall survival (OS) was 35\% (HPV - /p16 - ) vs $87 \%(\mathrm{HPV}+/ \mathrm{p} 16+, P<0.001)$ and $75 \%(\mathrm{HPV}-/ \mathrm{p} 16+, P=0.219)$. Disruptive mutations in TP53 were found in $80 \%$ of $\mathrm{HPV}-/ \mathrm{p} 16$ - tumours vs $6 \%$ of $\mathrm{HPV}+/ \mathrm{p} 16+$ tumours $(P<0.001)$. In multivariate analysis, HPV $-/ \mathrm{p} 16-$ status was an independent predictor of inferior LRC and OS.

Conclusions: HPV - tumours are frequently TP53 mutated. HPV - /P16 - status is a strong predictor for reduced LRC and OS, and alternative treatment strategies for patients with HPV - /p16 - disease need to be explored.

*Correspondence: Dr A Cats; E-mail: a.cats@nki.nl

Received 9 November 2014; revised 6 January 2015; accepted 12 January 2015

(c) 2015 Cancer Research UK. All rights reserved 0007-0920/15 
Squamous cell carcinoma of the anal canal (SCCAC) is a relatively rare malignancy with 1-2 per 100000 new cases in Europe and the United States each year, but its incidence is rising (Netherlands Cancer Registry; Nelson et al, 2013). Most patients present with locally advanced, non-metastasised disease, for which the established treatment is concurrent chemoradiotherapy, consisting of radiotherapy, combined with 5-fluorouracil (5-FU) and mitomycin C (MMC) (James et al, 2013). With standard treatment, complete and durable remission can be achieved in the majority of patients, with clinical complete response rates as high as $90 \%$, locoregional control (LRC) at 3 years of $70-80 \%$ and 3 -year overall survival (OS) of $80-85 \%$ (James et al, 2013). Ten to twenty per cent of the patients, however, do not respond to therapy or relapse early after treatment. Although several prognostic factors for unfavourable outcome have been identified - including male sex and high $\mathrm{T}$ - and $\mathrm{N}$-classification (Ajani et al, 2010) - these factors do not fully explain differences in outcome. Squamous cell carcinoma of the anal canal is known to be strongly linked with the human papillomavirus (HPV), a small double-stranded DNA virus commonly known for its role in the development of cervical cancer, other gynaecological cancers, and head and neck squamous cell carcinoma (HNSCC). The prevalence of high-risk HPV (HR$\mathrm{HPV}$ ) types in SCCAC - that is, those types associated with carcinogenesis - ranges from 70 to almost $100 \%$, depending on the population studied and the sensitivity of the method used for HPV detection (Daling et al, 2004; Hoots et al, 2009; Valmary-Degano et al, 2013). Human papillomavirus can induce carcinogenesis via expression of the oncoproteins E6 and E7, which act by inactivating the tumour suppressor proteins p53 and retinoblastoma protein $(\mathrm{pRb})$, respectively. Persisting inactivation of p53 and $\mathrm{pRb}$ leads to genomic instability and, upon persisting infection, to carcinogenesis. As $\mathrm{pRb}$ is a negative regulator of the cyclindependent kinase inhibitor $\mathrm{p} 16$, inactivation of $\mathrm{pRb}$ by HPV leads to marked upregulation of p16. For this reason, p16 overexpression, measured by immunohistochemistry, is often used as a surrogate marker for tumour HPV infection. A proportion of SCCAC tumours are found to be HPV-negative (HPV - ), that is, they do not carry HPV, or carry only low-risk HPV (LR-HPV) types - that is, types that are generally not associated with carcinogenesis. It has been demonstrated in patients with HNSCC that HPV - tumours have substantially worse outcome compared with patients with HPV + tumours. Overall survival at 3 years was $82 \%$ for patients with HPV + disease, compared with $57 \%$ for patients with HPV - disease $(P<0.001)$ (Ang et al, 2010). Also in cervical cancer, HPV - status is an unfavourable prognostic factor (Harima et al, 2002). The considerable differences in outcome of patients with HPV $+v s \mathrm{HPV}-$ tumours have been attributed to differences in tumour biology. Indeed, in HNSCC there are marked differences between HPV + and HPV - tumours at the level of mutational patterns, loss-of-heterozygosity, and chromosomal alterations (Braakhuis et al, 2004; Smeets et al, 2006; Stransky et al, 2011; Lechner et al, 2013). These differences might affect prognosis and effectiveness of treatment. A particularly striking difference between HPV + and HPV - HNSCC tumours are mutations in TP53 (the gene encoding p53). Whereas TP53 mutations are found only sporadically in HPV + HNSCC tumours (0-10\%), they occur very frequently in HPV - tumours, with disruptive mutations present in $80-100 \%$ of cases (Westra et al, 2008; Agrawal et al, 2011; Stransky et al, 2011; Lechner et al, 2013). TP53 mutations are of interest in particular, because they have been linked to prognosis in different types of cancer (Tandon et al, 2010; Stengel et al, 2014) and, in addition, to resistance to radiation therapy (Skinner et al, 2012; Kimple et al, 2013), which is an important treatment modality for SCCAC and most other HPVassociated cancers. To investigate the prognostic significance of HPV, p16, and alterations in p53 function in SCCAC, we determined associations with outcome of tumour HPV status, p16 expression, p53 expression, and mutations in TP53 in a cohort of 107 anal carcinoma patients treated with chemoradiotherapy or radiotherapy alone.

\section{MATERIALS AND METHODS}

Patients. All consecutive patients, $\geqslant 18$ years of age, with histologically confirmed locally advanced SCCAC, treated at our institute between August 2003 and August 2011 with chemoradiotherapy or radiotherapy alone were included. Patients with $\mathrm{T} 2-4(\mathrm{~T} \geqslant 4 \mathrm{~cm}), \mathrm{N} 0-1, \mathrm{M} 0$ or $\mathrm{T} 1-4, \mathrm{~N} 2-3, \mathrm{M} 0$ tumours were treated with concurrent chemoradiotherapy with a fluoropyrimidine (5-FU or capecitabine), MMC (10 $\mathrm{mg} \mathrm{m}^{-2}$ on day 1), and three-field conformal RT or IMRT. Patients with $T 1-2$ ( $T \geqslant 1$ and $<4 \mathrm{~cm}$ ), N0-1, M0 disease were treated with radiotherapy alone. Detailed treatment characteristics and inclusion criteria were reported previously (Meulendijks et al, 2014). In addition, patients with no paraffin-embedded tumour biopsy tissue available were excluded. Data collection was approved by the institutional ethics committee.

HPV DNA isolation, amplification, and genotyping. Formalinfixed paraffin-embedded (FFPE) tissue samples were sectioned to avoid contamination with HPV DNA from tissue to tissue. DNA was isolated from three $8-\mu \mathrm{m}$ sections using the cobas DNA Sample Preparation Kit (Roche Diagnostics, Indianapolis, IN, USA). Subsequently, HPV DNA was amplified using the SPF10 PCR primer set from the INNO-LiPA HPV Genotyping Extra Kit (Fujirebio Europe, Gent, Belgium). During each run, a negative control (water) and a positive control (HPV18 + sample) was analysed. SPF10 amplimers from HPV DNA-positive samples were subsequently analysed using an HPV Line Probe assay (LiPA) (Kleter et al, 1999). Here also, positive and negative controls were included in each analytical run. Human papillomavirus 6, 11, 40, $43,44,54,71$, and 74 were considered LR-HPV types, whereas HPV 16, 18, 26, 31, 33, 35, 39, 45, 51, 52, 53, 56, 58, 59, 66, 68, 69, 70,73 , and 82 were considered HR-HPV types. To minimise the risk of false-negative results, all samples that were HPV - were reanalysed with INNO-LiPA, and subsequently analysed with a second test, RealTime High Risk HPV (Abbott Diagnostics, Lake Forest, IL, USA).

Immunohistochemistry of p16 and p53. Immunohistochemistry (IHC) was performed on a BenchMark ULTRA autostainer (Ventana Medical Systems, Tucson, AZ, USA). Briefly, 4- $\mu \mathrm{m}$ paraffin sections were cut, heated for $28 \mathrm{~min}$ at $75^{\circ} \mathrm{C}$, and deparaffinised in the instrument using EZ prep solution (Ventana Medical Systems). Heat-induced antigen retrieval was carried out using Cell Conditioning 1 (Ventana Medical Systems) for $36 \mathrm{~min}$ at $95^{\circ} \mathrm{C}$. To detect p16, sections were incubated for $32 \mathrm{~min}$ with antibody clone JC8 (ILM8763-C1; ImmunoLogic, Duiven, the Netherlands). For p53, antibody clone DO-7 (M7001; Dako, Glostrup, Denmark) was used (incubation $32 \mathrm{~min}$ ). After incubation with the primary antibodies, the Amplification Kit (Ventana Medical Systems) was applied. Specific reactions were detected using UltraView Universal DAB Detection Kit (Ventana Medical Systems), and slides were counterstained with haematoxylin. Protein expression scoring was performed by two investigators (MFV and DM) who were not aware of patient identity. In case of discrepant scoring, consensus was reached between the investigators. Staining of p16 was scored as positive $(\mathrm{p} 16+)$ when $\geqslant 70 \%$ of the tumour cells showed strong nuclear staining, as opposed to negative in case $<70 \%$ of cells showed strong nuclear staining (p16 - ) (Ang et al, 2010). Expression of p53 was scored as nonaberrant when 1-70\% of cells showed strong nuclear staining, or as aberrant when either $>70 \%$ or $0 \%$ of the tumour cells showed strong nuclear staining (Yemelyanova et al, 2011). 
TP53 mutational analysis. TP53 mutational analysis was performed in all patients with HPV - tumours $(n=14)$, and 18 randomly selected patients with $\mathrm{HPV}+$ disease. Exons $2-11$ of TP53 were amplified using PCR on genomic DNA derived from FFPE tumour tissue (primer sequences available upon request). Purified PCR reaction products were then sequenced using BigDye Terminator v.1.1 (Applied Biosystems, Foster City, CA, USA). The sequence fragments were analysed using an automated sequencer (ABI3730; Applied Biosystems) and data were analysed using Mutation Surveyor (Softgenetics LLC, State College, PA, USA). The TP53 database of the International Agency for Research on Cancer (IARC, Lyon, France; http://p53.iarc.fr) was used to determine the functional consequences of TP53 mutations. Mutations without functional consequences were considered non-disruptive; mutations resulting in a completely or partially dysfunctional protein were grouped as disruptive mutations.

End points and statistical analysis. Patient demographics and disease characteristics of groups according to HPV/p16 status were described by means of descriptive statistics and compared using Student's $t$-test (age), Mann-Whitney $U$-test (T-classification, $\mathrm{N}$-classification, UICC stage), or Fisher's exact test (gender, SCC antigen, HIV status, smoking status). The primary end points of the study were LRC and OS, as a function of tumour HPV status, p16 expression, p53 expression, and TP53 mutational status. Thus, patients were grouped based on the presence or absence of HR-HPV in tumour (HPV $+v s$ HPV -$)$, p16 expression (p16 + vs p16 - ), p53 expression (non-aberrant $v s$ aberrant expression), and the presence of disruptive mutations in TP53 (disruptive mutation present $v s$ absent). Locoregional control and OS were defined as the time between the first day of treatment and the day on which clinical signs of progression (at the primary site or regional, inguinal, or pelvic lymph nodes) or death of any cause occurred, respectively. Locoregional control and OS were compared between groups using log-rank tests. For multivariate analysis of factors related to outcome, a Cox regression model was used in which covariates that were significant upon univariate analysis were included. TP53 mutations were not included in the multivariate analysis as only a limited number of tumours was analysed. The influence of HPV/p16 status and p53 expression on outcome was analysed separately in the entire cohort and in the subgroup of patients with early-stage tumours treated with radiotherapy alone. All statistical tests were two-sided, with the threshold for significance set at $P<0.05$. Statistical analyses were performed using SPSS version 17.0 (SPSS, Chicago, IL, USA).

\section{RESULTS}

Patients. Of 138 patients treated between August 2003 and August 2011, 107 met the in- and exclusion criteria. Of all tumours, 93 were found to be HPV +/p16 + (87\%), 4 were HPV - /p16+ (4\%), and 10 were $\mathrm{HPV}-/ \mathrm{p} 16-(9 \%)$. Patient characteristics according to HPV/p16 status are shown in Table 1. Patients with HPV - tumours were more often males compared with patients with HPV + tumours $(86 \%$ vs $44 \%, P=0.003)$. The individual groups of $\mathrm{HPV}-/ \mathrm{p} 16+$ and $\mathrm{HPV}-/ \mathrm{p} 16-$ patients were also more often males than patients with $\mathrm{HPV}+/ \mathrm{p} 16+$ tumours $(P=0.032$ and $P=0.019$, respectively). T-classification, N-classification, and UICC stage did not differ significantly between groups, although HPV - tumours tended to have higher T-classification $(P=0.074)$.

HPV genotyping. All 107 tissues could be genotyped for HPV DNA. The detected HPV types are summarised in Table 2. As expected, HPV16 was the most prevalent HR-HPV type, accounting for 81 out of $93(87 \%)$ of all HPV + tumours. Based on the results of the INNO-LiPA test, initially six discordant cases
$(\mathrm{HPV}-/ \mathrm{p} 16+)$ were identified. These were reanalysed with INNO-LiPA, and subsequently with the secondary HPV test. Four out of six tumours were confirmed to be HPV - , whereas two cases showed to be positive on reanalysis with the second assay (one HPV18 + case and one case HR-HPV + not otherwise specified).

Immunohistochemistry of p16 and p53. All HR-HPV + tumours were also p16+, which included 93 out of 107 patients (85\%). Of the remaining $14 \mathrm{HPV}$-negative tumours, 10 out of 14 were $\mathrm{HPV}-/ \mathrm{p} 16-$, and 4 out of 14 were HPV $-/ \mathrm{p} 16+$. The four tumours carrying the LR-HPV type 6, shown in Table 2, were all p16- . Overall, 14 out of 107 tumours (13\%) showed aberrant p53 expression patterns, of which two showed $0 \%$ staining (both were $\mathrm{HPV}-/ \mathrm{p} 16-$ ). Aberrant p53 expression was more frequent in $\mathrm{HPV}-/ \mathrm{p} 16$ - tumours (5 out of $10,50 \%$ ) than in $\mathrm{HPV}+/ \mathrm{p} 16+$ tumours ( 9 out of $93,10 \%, P=0.004$; Figure $1 \mathrm{~A}$ ). Among the HPV - /p16 + tumours, $0(0 \%)$ had aberrant p53 expression. Figures of representative immunohistochemical stainings for p16 and p53 are available in the Supplementary Material (Supplementary Figure S1).

TP53 mutational analyses. Sequences of exons 2-11 of TP53 could be determined in 31 of (all) $14 \mathrm{HPV}$ - and 18 selected $\mathrm{HPV}+$ samples. DNA quality of one sample (of a HPV $-/ \mathrm{p} 16+$ patient) did not permit reliable interpretation of results. The distribution of disruptive TP53 mutations according to HPV/p16 status is depicted in Figure 1B, showing that mutations were far more prevalent in HPV - tumours than in HPV + tumours. Disruptive mutations were found in 1 out of $18(6 \%) \mathrm{HPV}+1$ p16 + tumours, 1 out of $3(33 \%) \mathrm{HPV}-/ \mathrm{p} 16+$, and 8 out of 10 (80\%) HPV - /p16 - tumours. In addition, in the HPV +/p16+ group one mutation that is classified as non-disruptive was detected. The detected variants are summarised in Table 3. Of six tumours that had aberrant expression on IHC, 5 out of 6 were TP53 mutation positive (83\%). Of 26 tumours that were nonaberrant on IHC, 20 (77\%) did not carry a TP53 mutation. Of 10 tumours that carried a TP53 mutation, five were aberrant on IHC (50\%).

Outcome in relation to HPV status and p16 expression. Locoregional control and OS were strongly influenced by HPV/p16 status. Figure 2 shows the outcome of patients according to $\mathrm{HPV} / \mathrm{p} 16$ status. Patients with HPV -/p16 - tumours had significantly inferior 3-year LRC (15\%) compared with $\mathrm{HPV}+/ \mathrm{p} 16+$ tumours (82\%, $P<0.001)$ and $\mathrm{HPV}-/ \mathrm{p} 16+$ tumours $(75 \%$, $P=0.078$ ). Overall survival at 3 years was $35 \%$ for patients with $\mathrm{HPV}-/ \mathrm{p} 16$ - tumours compared with $87 \%$ for $\mathrm{HPV}+/ \mathrm{p} 16+$ tumours $(P<0.001$ compared with HPV $-/ \mathrm{p} 16-)$ and $75 \%$ for $\mathrm{HPV}-/ \mathrm{p} 16+(P=0.219$ compared with $\mathrm{HPV}-/ \mathrm{p} 16-)$. Among the patients who died during follow-up, in the HPV - /p16 - group 5 out of 6 patients $(83 \%)$ died owing to anal cancer, and in the $\mathrm{HPV}+/ \mathrm{p} 16+$ group, 7 out of 11 patients (64\%). The only deceased patient in the HPV $-/$ p $16+$ group died of anal cancer. We did not identify distinct patterns of local or distant recurrence for $\mathrm{HPV}+v s \mathrm{HPV}$ - tumours. Distant recurrence occurred in seven patients $(8 \%)$ in the $\mathrm{HPV}+/ \mathrm{p} 16+$ group (distant lymph nodes, four patients; liver, two patients; lung, one patient), and in 1 out of 16 patients (6\%) in the HPV - group (skeletal). In the subgroup of patients with early-stage tumours who received radiotherapy alone, LRC and OS were also strongly influenced by $\mathrm{HPV} / \mathrm{p} 16$ status (Supplementary Figure S2). Locoregional control at 3 years was $0 \%$ for patients with $\mathrm{HPV}-/ \mathrm{p} 16-$ tumours compared with $85 \%$ for $\mathrm{HPV}+/ \mathrm{p} 16+$ tumours $(P<0.001)$. Similarly, OS was $33 \%$ vs $100 \%(P=0.002)$. There were no $\mathrm{HPV}-/ \mathrm{p} 16+$ patients treated with radiotherapy alone.

Outcome in relation to p53 expression and TP53 alterations. Both aberrant p53 expression and TP53 mutations were associated 
Table 1. Patient and disease characteristics by HPV and p16 status

\begin{tabular}{|c|c|c|c|c|c|}
\hline Characteristic & $\begin{array}{l}\text { Overall } \\
(n=107)\end{array}$ & $\begin{array}{l}\mathrm{HPV}+/ \mathrm{p} 16+ \\
\quad(n=93)\end{array}$ & $\begin{array}{l}\mathrm{HPV}-/ \mathrm{p} 16+ \\
\quad(n=4)\end{array}$ & $\begin{array}{l}\mathrm{HPV}-/ \mathrm{p} 16- \\
\quad(n=10)\end{array}$ & $\begin{array}{c}\text { P-value } \\
(\mathrm{HPV}+\text { vs HPV }-)\end{array}$ \\
\hline Age, median (range) ${ }^{\mathbf{a}}$ & $60(34-86)$ & $60(34-86)$ & $58(43-70)$ & $61(46-74)$ & 0.894 \\
\hline \multicolumn{6}{|l|}{ Sex } \\
\hline $\begin{array}{l}\text { Male } \\
\text { Female }\end{array}$ & $\begin{array}{l}50(47 \%) \\
57(53 \%)\end{array}$ & $\begin{array}{l}38(41 \%) \\
55(59 \%)\end{array}$ & $\begin{array}{l}4(100 \%) \\
0(0 \%)\end{array}$ & $\begin{array}{l}8(80 \%) \\
2(20 \%)\end{array}$ & 0.003 \\
\hline \multicolumn{6}{|l|}{ T-classification } \\
\hline $\begin{array}{l}\text { T1 } \\
\text { T2 } \\
\text { T3 } \\
\text { T4 }\end{array}$ & $\begin{array}{c}4(4 \%) \\
53(50 \%) \\
32(30 \%) \\
18(17 \%)\end{array}$ & $\begin{array}{c}4(4 \%) \\
49(53 \%) \\
25(27 \%) \\
15(16 \%)\end{array}$ & $\begin{array}{c}0(0 \%) \\
0(0 \%) \\
4(100 \%) \\
0(0 \%)\end{array}$ & $\begin{array}{c}0(0 \%) \\
4(40 \%) \\
3(30 \%) \\
3(30 \%)\end{array}$ & 0.074 \\
\hline \multicolumn{6}{|l|}{ N-classification } \\
\hline $\begin{array}{l}\text { N0 } \\
\text { N1 } \\
\text { N2 } \\
\text { N3 } \\
\text { Nx }\end{array}$ & $\begin{array}{c}49(46 \%) \\
30(28 \%) \\
18(17 \%) \\
9(8 \%) \\
1(1 \%)\end{array}$ & $\begin{array}{c}40(43 \%) \\
30(32 \%) \\
13(14 \%) \\
9(10 \%) \\
1(1 \%)\end{array}$ & $\begin{array}{c}3(75 \%) \\
0(0 \%) \\
1(25 \%) \\
0(0 \%) \\
0(0 \%)\end{array}$ & $\begin{array}{l}6(60 \%) \\
0(0 \%) \\
4(40 \%) \\
0(0 \%) \\
0(0 \%)\end{array}$ & 0.383 \\
\hline \multicolumn{6}{|l|}{ UICC stage } \\
\hline $\begin{array}{l}\text { Stage 0 } \\
\text { Stage I } \\
\text { Stage II } \\
\text { Stage III } \\
\text { Stage IV } \\
\text { Not known }\end{array}$ & $\begin{array}{c}0(0 \%) \\
5(5 \%) \\
36(34 \%) \\
65(61 \%) \\
0(0 \%) \\
1(1 \%)\end{array}$ & $\begin{array}{c}0(0 \%) \\
5(5 \%) \\
29(31 \%) \\
58(62 \%) \\
0(0 \%) \\
1(1 \%)\end{array}$ & $\begin{array}{c}0(0 \%) \\
0(0 \%) \\
3(75 \%) \\
1(25 \%) \\
0(0 \%) \\
0(0 \%)\end{array}$ & $\begin{array}{c}0(0 \%) \\
0(0 \%) \\
4(40 \%) \\
6(60 \%) \\
0(0 \%) \\
0(0 \%)\end{array}$ & 0.429 \\
\hline \multicolumn{6}{|l|}{ HIV status } \\
\hline $\begin{array}{l}\text { Negative } \\
\text { Positive } \\
\text { Not known }\end{array}$ & $\begin{array}{l}34(31 \%) \\
10(9 \%) \\
63(59 \%)\end{array}$ & $\begin{array}{l}27(30 \%) \\
10(11 \%) \\
54(59 \%)\end{array}$ & $\begin{array}{l}3(75 \%) \\
0(0 \%) \\
1(25 \%)\end{array}$ & $\begin{array}{l}2(20 \%) \\
0(0 \%) \\
8(80 \%)\end{array}$ & 0.573 \\
\hline \multicolumn{6}{|l|}{ Smoking status } \\
\hline $\begin{array}{l}\text { Smoker } \\
\text { Non-smoker } \\
\text { Ex-smoker } \\
\text { Not known }\end{array}$ & $\begin{array}{c}31 \text { (29\%) } \\
9 \text { (8\%) } \\
13(12 \%) \\
54(50 \%)\end{array}$ & $\begin{array}{c}26(28 \%) \\
8(9 \%) \\
12(13 \%) \\
47(51 \%)\end{array}$ & $\begin{array}{ll}1 & (25 \%) \\
1 & (25 \%) \\
1 & (25 \%) \\
1 & (25 \%)\end{array}$ & $\begin{array}{l}4(40 \%) \\
0(0 \%) \\
0(0 \%) \\
6(60 \%)\end{array}$ & $1.000^{b}$ \\
\hline \multicolumn{6}{|l|}{ SCC antigen } \\
\hline $\begin{array}{l}\text { Normal }\left(<2.0 \mu \mathrm{gl}^{-1}\right) \\
\text { Elevated } \\
\text { Not known }\end{array}$ & $\begin{array}{c}62(58 \%) \\
38(36 \%) \\
7(7 \%)\end{array}$ & $\begin{array}{c}51(55 \%) \\
36(39 \%) \\
6(6 \%)\end{array}$ & $\begin{array}{l}3(75 \%) \\
1(25 \%) \\
0(0 \%)\end{array}$ & $\begin{array}{l}8(80 \%) \\
1(10 \%) \\
1(10 \%)\end{array}$ & 0.123 \\
\hline \multicolumn{6}{|l|}{ Treatment } \\
\hline $\begin{array}{l}\text { IMRT only } \\
5-F U+M M C+R T / I M R T \\
\text { CAP + MMC + IMRT }\end{array}$ & $\begin{array}{l}16(15 \%) \\
44(41 \%) \\
47(44 \%)\end{array}$ & $\begin{array}{l}13(14 \%) \\
37(40 \%) \\
43(46 \%)\end{array}$ & $\begin{array}{l}0(0 \%) \\
3(75 \%) \\
1(25 \%)\end{array}$ & $\begin{array}{l}3(30 \%) \\
4(40 \%) \\
3(30 \%)\end{array}$ & - \\
\hline \multicolumn{6}{|l|}{ Radiation dose } \\
\hline $\begin{array}{l}\text { Total radiation dose to primary tumour, median (range) } \\
\text { Total radiation dose to LNs, median (range) }\end{array}$ & $\begin{array}{l}64.8(59.4-70.2) \\
54.9(45.0-66.6)\end{array}$ & $\begin{array}{l}64.8(59.4-70.2) \\
54.9(45.0-70.2)\end{array}$ & $\begin{array}{l}64.8(59.4-68.4) \\
54.9(49.5-68.4)\end{array}$ & $\begin{array}{l}64.8(59.4-64.8) \\
54.9(45.0-64.8)\end{array}$ & - \\
\hline \multicolumn{6}{|c|}{ 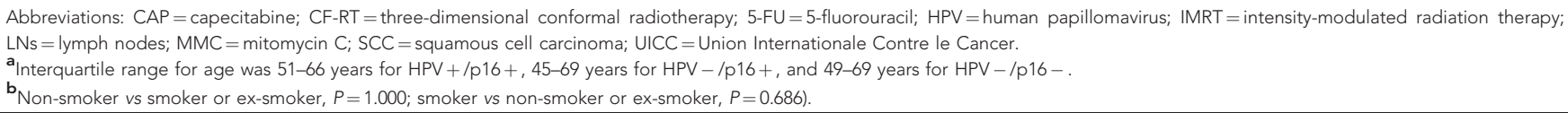 } \\
\hline
\end{tabular}

with inferior LRC in univariate analysis (Figure 3). Within the group of $\mathrm{HPV}+/ \mathrm{p} 16+$ patients, p53 expression pattern did not predict for response ( $P=0.280$ and $P=0.656$, not shown). Within the HPV - group, patients with aberrant p53 expression patterns tended to have inferior LRC $(P=0.095)$ and inferior OS $(P=0.108)$ compared with patients with non-aberrant expression (Supplementary Figure S3A and B). In contrast, outcome of patients with TP53 mutations in the HPV - group was not significantly different from outcome of patients without detected TP53 mutations in the same group $(P=0.349$ and $P=0.477$; Supplementary Figure S3C and D), suggesting that TP53 mutational status per se was not a prognostic factor in HPV tumours. The single patient with a disruptive TP53 mutation in the $\mathrm{HPV}+$ group achieved complete response and was disease-free at last follow-up 2.5 years after finishing treatment.
Multivariate analysis of prognostic factors. Subsequently, multivariate analyses of LRC and OS were performed by including covariates that were significant in univariate analysis. Table 4 summarises the results of these analyses. Human papillomavirus -/p16 - status and male sex were both independently associated with reduced LRC. Furthermore, HPV $-/ \mathrm{p} 16$ - status as well as higher T-classification were independently prognostic for reduced OS.

\section{DISCUSSION}

In this large single institute cohort of patients with SCCAC given standard of care treatment, we show that HPV and p16 status are 


\begin{tabular}{|c|c|}
\hline HR-HPV positive & $93(87 \%)$ \\
\hline Single HR-HPV type & 80 (75\%) \\
\hline HPV16 & 71 \\
\hline HPV18 & 4 \\
\hline HPV31 & 1 \\
\hline HPV33 & 1 \\
\hline HPV56 & 1 \\
\hline HPV82 & 1 \\
\hline Other HR type (not specified) & 1 \\
\hline Combinations with HPV 16 & $10(9 \%)$ \\
\hline HPV $16+52$ & 4 \\
\hline HPV $16+18$ & 1 \\
\hline HPV16 $+33+66+6+43+74$ & 1 \\
\hline $\mathrm{HPV} 16+39 / 68+70$ & 1 \\
\hline HPV16 + 11 & 1 \\
\hline HPV16 + 51 & 1 \\
\hline HPV16 + 6 & 1 \\
\hline Combinations of other HR-HPV & $3(3 \%)$ \\
\hline HPV18 + 82+ 74 & 1 \\
\hline HPV31 + 44 & 1 \\
\hline HPV $35+52$ & 1 \\
\hline HR-HPV negative & $14(13 \%)$ \\
\hline No HPV & $10(9 \%)$ \\
\hline None detected & 10 \\
\hline LR-HPV & $4(4 \%)$ \\
\hline HPV6 & 4 \\
\hline \multicolumn{2}{|c|}{$\begin{array}{l}\text { Abbreviations: HPV = human papillomavirus; } H R-H P V=\text { high-risk } H P V ; ~ L R-H P V=l o w-r i s h \\
\text { HPV. }\end{array}$} \\
\hline
\end{tabular}

strong predictors for LRC and OS. Outcome of patients with HPV - /p16 - tumours was considerably inferior compared with patients with $\mathrm{HPV}+/ \mathrm{p} 16+$ tumours, and $\mathrm{HPV}-/ \mathrm{p} 16-$ status was an independent prognostic factor for reduced LRC and OS. Disruptive alterations in TP53 were frequently found in $\mathrm{HPV}-/ \mathrm{p} 16$ - tumours (80\%), compared with only sporadically in the tested HPV $+/ \mathrm{p} 16+$ tumours $(6 \%)$.

We used a highly sensitive method to detect HPV DNA, which is considered the gold standard and is able to detect most HPV types. The distribution of HPV types, with HPV16 being the most prevalent HR-HPV type in HPV + tumours, is in accordance with previous studies investigating the prevalence of HPV in SCCAC (Daling et al, 2004; Hoots et al, 2009; Valmary-Degano et al, 2013). In our study, not all HPV - tumours were also p16 - . In fact, 4 out of 16 (25\%) of the HPV - tumours showed overexpression of p16, to a similar extend as HPV + tumours. This is consistent with a previous study by Serup-Hansen et al (2014), who also showed that a proportion of HPV - SCCAC tumours was p16 positive. However, their finding was attributed to insufficient sensitivity of the HPV assay used. In the current study, a highly sensitive detection method was used and additional analyses were performed to preclude that these cases are false negatives. For these reasons, we believe it is plausible that these tumours are truly HPV - . Patients with HPV $-/ \mathrm{p} 16+$ tumours differed from patients with $\mathrm{HPV}+/ \mathrm{p} 16+$ tumours, in that the former were exclusively males, whereas among $\mathrm{HPV}+/ \mathrm{p} 16+$ patients, there were slightly more women. There was a trend towards better LRC in these patients compared with $\mathrm{HPV}-/ \mathrm{p} 16$ - patients, but it concerned a very small number of patients and could well be a chance finding. It has been demonstrated in orophyrangeal squamous cell carcinoma (OSCC) also that a subset of HPV tumours is p16 positive (Rietbergen et al, 2014). Rietbergen et al (2014) characterised a series of these discordant, HPV $-/ \mathrm{p} 16+$ cases of OSCC, and found that patterns of loss-of-heterozygosity
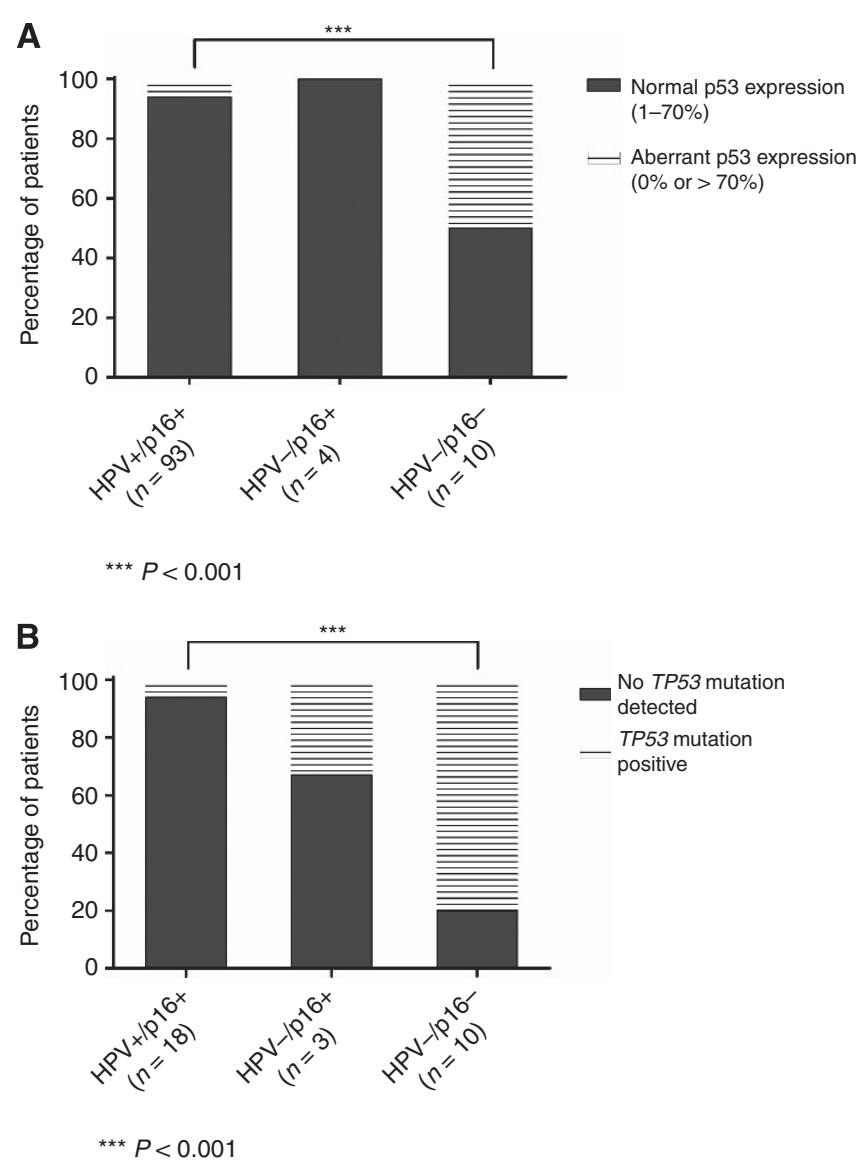

Figure 1. Expression patterns of p53 and disruptive TP53 mutations according to HPV/p16 status. Distribution of p53 expression patterns (A) and disruptive TP53 mutations (B) among groups according to $\mathrm{HPV} / \mathrm{p} 16$ status.

characterised these tumours as HPV - rather than HPV + . The mechanism of overexpression of p16 in these tumours, if truly $\mathrm{HPV}-$, could be related to mutations in genes of other tumour suppressor proteins, including $R B 1$. Our findings with respect to concordance between HPV and p16 status in SCCAC are in line with reports in HNSSC (Rietbergen et al, 2014), and suggest that p16 is not a perfect surrogate marker for tumour HPV status. Thus, although p16 IHC has high sensitivity, specificity might be insufficient, and the use of HPV PCR could still be required if SCCAC patients were to be stratified based on HPV status (e.g. for the purpose of future clinical studies). We showed that disrupted p53 function, measured as disruptive TP53 mutations, was far more common in patients with HPV - /p16 - tumours than in $\mathrm{HPV}+/ \mathrm{p} 16+$ tumours. This inverse relationship between $\mathrm{HPV}+$ status and TP53 mutations has also been demonstrated in HNSCC (Westra et al, 2008; Stransky et al, 2011), and might indicate, as is thought to be the case in HNSCC (Boyle et al, 1993; Nees et al, 1993), that disruption of p53 function is a key mechanism for HPV - SCCAC tumours to evolve. It is not surprising that mutations in TP53 are found only sporadically in $\mathrm{HPV}+$ tumours, as the HPV oncoprotein E6 inhibits p53 function by targeting it for ubiquitination and degradation. An additional mutation in TP53 would, therefore, not be required for these tumours to evolve. The apparent lower frequency of TP53 mutations in $\mathrm{HPV}-/ \mathrm{p} 16+$ tumours could be explained by aberrations in other tumour suppressor proteins, which could be investigated in future studies. Concordance between p53 immunohistochemistry and TP53 mutational analysis was low. This might explain why in most previous studies no association between 
Table 3. Results from TP53 mutational analysis (exons 2-11) according to HPV/p16 status

\begin{tabular}{|c|c|c|c|c|c|c|}
\hline Patient & HPV/p16 status & $\begin{array}{l}\text { Percentage p53 } \\
\text { staining }\end{array}$ & $\begin{array}{l}\text { TP53 mutations } \\
\text { detected }\end{array}$ & Exon & $\begin{array}{l}\text { Effect on p53 } \\
\text { protein }\end{array}$ & $\begin{array}{l}\text { Functional } \\
\text { consequence }^{a}\end{array}$ \\
\hline \multicolumn{7}{|c|}{$\mathrm{HPV}+/ \mathrm{p} 16+$} \\
\hline 1 & $\mathrm{HPV}+/ \mathrm{p} 16+$ & 20 & - & - & - & - \\
\hline 2 & $\mathrm{HPV}+/ \mathrm{p} 16+$ & 60 & c. $592 \mathrm{G}>\mathrm{A}$ & 6 & p.E198K & Functional \\
\hline 3 & $\mathrm{HPV}+/ \mathrm{p} 16+$ & 20 & - & - & - & - \\
\hline 4 & $\mathrm{HPV}+/ \mathrm{p} 16+$ & 20 & - & - & - & - \\
\hline 5 & $\mathrm{HPV}+/ \mathrm{p} 16+$ & 40 & - & - & - & - \\
\hline 6 & $\mathrm{HPV}+/ \mathrm{p} 16+$ & 70 & - & - & - & - \\
\hline 7 & $\mathrm{HPV}+/ \mathrm{p} 16+$ & 1 & $-{ }^{b}$ & - & - & - \\
\hline 8 & $\mathrm{HPV}+/ \mathrm{p} 16+$ & 1 & c. 455 del 1 & 5 & p.P152fs & Non-functional \\
\hline 9 & $\mathrm{HPV}+/ \mathrm{p} 16+$ & 20 & - & - & - & - \\
\hline 10 & $\mathrm{HPV}+/ \mathrm{p} 16+$ & 10 & - & - & - & - \\
\hline 11 & $\mathrm{HPV}+/ \mathrm{p} 16+$ & 50 & - & - & - & - \\
\hline 12 & $\mathrm{HPV}+/ \mathrm{p} 16+$ & 10 & - & - & - & - \\
\hline 13 & $\mathrm{HPV}+/ \mathrm{p} 16+$ & 30 & - & - & - & - \\
\hline 14 & $\mathrm{HPV}+/ \mathrm{p} 16+$ & 10 & - & - & - & - \\
\hline 15 & $\mathrm{HPV}+/ \mathrm{p} 16+$ & 10 & - & - & - & - \\
\hline 16 & $\mathrm{HPV}+/ \mathrm{p} 16+$ & 50 & - & - & - & - \\
\hline 17 & $\mathrm{HPV}+/ \mathrm{p} 16+$ & 1 & - & - & - & - \\
\hline 18 & $\mathrm{HPV}+/ \mathrm{p} 16+$ & 30 & - & - & - & - \\
\hline \multicolumn{7}{|c|}{ HPV - /p16 + } \\
\hline 19 & $\mathrm{HPV}-/ \mathrm{p} 16+$ & 20 & - & - & - & - \\
\hline 20 & $\mathrm{HPV}-/ \mathrm{p} 16+$ & 10 & - & - & - & - \\
\hline 21 & $\mathrm{HPV}-/ \mathrm{p} 16+$ & 60 & c. $844 \mathrm{C}>\mathrm{T}$ & 8 & p.R282W & Non-functional \\
\hline \multicolumn{7}{|c|}{ HPV - /p16 - } \\
\hline 22 & $\mathrm{HPV}-/ \mathrm{p} 16-$ & 90 & c.466del1 & 5 & p.R156fs & Non-functional \\
\hline 23 & $\mathrm{HPV}-/ \mathrm{p} 16-$ & 60 & c. $844 C>T$ & 8 & p.R282W & Non-functional \\
\hline 24 & $\mathrm{HPV}-/ \mathrm{p} 16-$ & 50 & - & - & - & - \\
\hline 25 & $\mathrm{HPV}-/ \mathrm{p} 16-$ & 0 & c.801_802del & 8 & p.A268fs & Non-functional \\
\hline 26 & $\mathrm{HPV}-/ \mathrm{p} 16-$ & 20 & c. $770 \mathrm{~T}>\mathrm{G}$ & 7 & p.L257R & Non-functional \\
\hline 27 & $\mathrm{HPV}-/ \mathrm{p} 16-$ & 10 & - & - & - & - \\
\hline 28 & $\mathrm{HPV}-/ \mathrm{p} 16-$ & 100 & c. $568 \mathrm{C}>\mathrm{A}$ & 6 & p.P190T & Partially functional \\
\hline 29 & HPV - /p16- & 95 & c. $844 C>T$ & 8 & p.R282W & Non-functional \\
\hline 30 & $\mathrm{HPV}-/ \mathrm{p} 16-$ & 0 & c.176_194dup & 4 & p.M66fs & Non-functional \\
\hline & & & c. $637 \mathrm{C}>\mathrm{T}$ & 6 & p.R213X & \\
\hline 31 & HPV - /p16- & 50 & c. $854 \mathrm{~A}>\mathrm{T}$ & 8 & p.E285V & Non-functional \\
\hline \multicolumn{7}{|c|}{$\begin{array}{l}\text { Abbreviations: HPV = human papillomavirus; IARC = International Agency for Research on Cancer. } \\
{ }^{a} \text { Data from the IARC TP53 database (Kato et al, 2003). }\end{array}$} \\
\hline
\end{tabular}

p53 overexpression and outcome has been found (Lampejo et al, 2010). Our results indicate that p53 immunohistochemistry is inadequate as a surrogate measure to detect TP53 mutations in SCCAC. The current concept in HNSCC is that HPV + and HPV - tumours develop by at least two different pathways: one driven by exposure to oncoproteins expressed by HPV and the other by exposure to environmental carcinogens (such as alcohol and tobacco) without HPV involvement. Although it is unlikely that these same carcinogens are the main inducers of HPV SCCAC, our study suggests that there might indeed be relevant differences in the genetic constitution of SCCAC tumours based on HPV status. From our results, and those of previous studies, it appears that male sex is associated with the development of HPV - SCCAC (Gilbert et al, 2013; Rödel et al, 2014; SerupHansen et al, 2014). Which other intrinsic and environmental factors are associated with HPV - SCCAC remains to be established. Loss of p53 function has been linked to resistance to radiotherapy (Lu and El-Deiry, 2009; Skinner et al, 2012; Kimple et al, 2013). It is therefore conceivable that patients with HPV - tumours have inferior treatment response owing to a higher frequency of disrupted p53 function (via TP53 mutations). However, we did not find strong evidence to support this hypothesis, as there were no differences in outcome between patients with and without disruptive mutations in the subgroup of HPV - patients. These findings could either indicate that TP53 mutations do not have an important role in treatment resistance of $\mathrm{HPV}-$ tumours or that additional (genetic) alterations in the subset of HPV - tumours contribute equally to treatment resistance (i.e. in tumours that do not carry TP53 mutations). We identified sporadic TP53 mutations in HPV + tumours, as has also been demonstrated in HNSCC (Lechner et al, 2013). It will be of interest to investigate which other genetic differences in HPV + and HPV - SCCAC tumours are related to outcome, as these differences might eventually provide an explanation for why HPV - tumours, and a subset of HPV + tumours, are not responsive to standard treatment.

A limitation of our study is that it is retrospective in nature, and the number of patients studied was relatively small. Notwithstanding this, HPV status as a prognostic factor in SCCAC has also been recognised by others, and several studies have now shown that patients with HPV - and/or p16 - disease have significantly worse outcome (Yhim et al, 2011; Gilbert et al, 2013; Rödel et al, 2014; Serup-Hansen et al, 2014). The prognostic significance of lack of p16 expression appears to be considerable, and it is striking that OS of patients with HPV - tumours appears to be reduced despite the fact that surgical salvage treatment is generally an effective treatment for most patients with locoregional relapse. We did not observe distinct patterns of relapse, but this should preferably be investigated in a larger population. Although it remains to be established why treatment resistance occurs, it is also unknown which could be effective treatment strategies for these patients. In a recent small study in patients with recurrent disease, the efficacy of docetaxel with cisplatin and 5-FU was described in patients with p16+ 

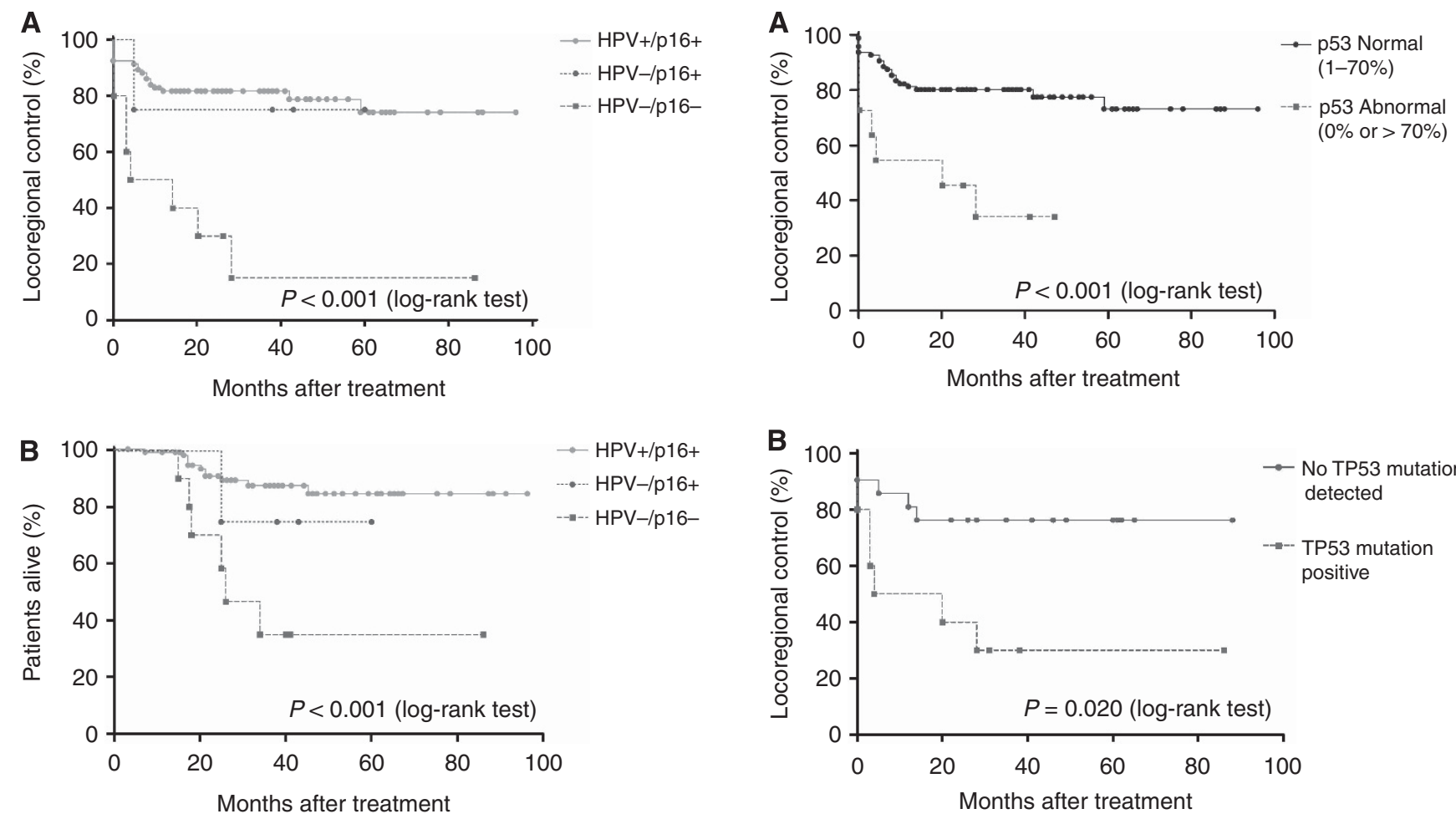

Figure 2. Outcome of patients according to HPV/p16 status.

Locoregional control (A) and overall survival (B) of patients according to HPV/p16 status. The P-value represents an overall comparison of the three groups presented in the figure. Pairwise comparisons are given in the text.

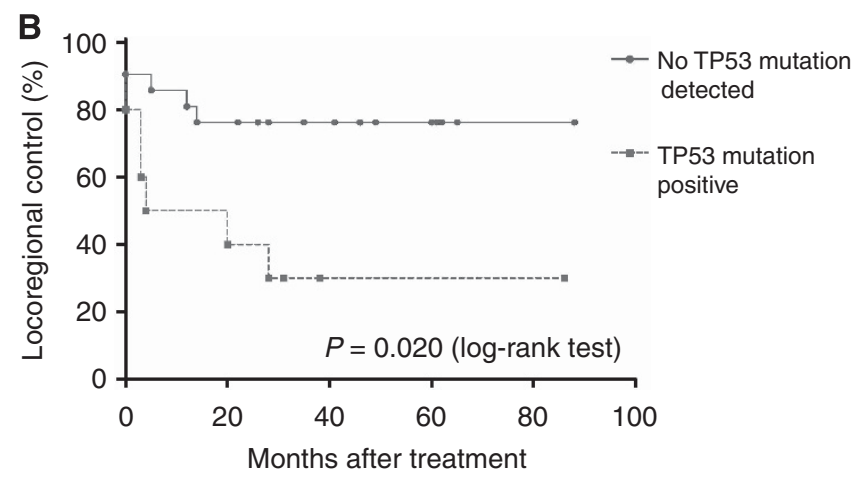

Figure 3. Outcome of patients according to $p 53$ expression and TP53 mutations. Locoregional control of patients according to p53 expression as measured by immunohistochemistry (A) and the presence of TP53 mutations (B).

\section{Table 4. Multivariate analysis of prognostic factors associated with locoregional control and overall survival}

\begin{tabular}{|c|c|c|c|c|c|c|c|c|}
\hline \multirow[b]{3}{*}{ Prognostic factor } & \multicolumn{4}{|c|}{ Locoregional control } & \multicolumn{4}{|c|}{ Overall survival } \\
\hline & \multicolumn{2}{|c|}{ Univariate } & \multicolumn{2}{|c|}{ Multivariate $^{a}$} & \multicolumn{2}{|c|}{ Univariate } & \multicolumn{2}{|c|}{ Multivariate $^{a}$} \\
\hline & HR & $P$-value & HR & $P$-value & HR & $P$-value & HR & $P$-value \\
\hline \multicolumn{9}{|l|}{ HPV/p16 status ${ }^{b}$} \\
\hline $\mathrm{HPV}+/ \mathrm{p} 16+$ & 1.00 & & 1.00 & & 1.00 & & 1.00 & \\
\hline HPV $-/ p 16+$ & $1.19(0.16-8.89)$ & 0.867 & $0.75(0.09-5.54)$ & 0.753 & $1.10(0.14-8.51)$ & 0.929 & $0.95(0.12-7.57)$ & 0.961 \\
\hline $\mathrm{HPV}-/ \mathrm{p} 16-$ & $5.59(2.43-12.87)$ & $<0.001$ & $2.76(1.01-7.56)$ & 0.049 & $5.69(2.09-15.50)$ & 0.001 & $4.37(1.59-12.07)$ & 0.004 \\
\hline \multicolumn{9}{|l|}{ P53 expression } \\
\hline P53 non-aberrant (1-70\%) & 1.00 & & 1.00 & & 1.00 & & & \\
\hline P53 aberrant ( $>70$ or $0 \%)$ & $4.07(1.71-9.67)$ & 0.002 & $2.39(0.85-6.72)$ & 0.100 & $2.71(0.89-8.23)$ & 0.080 & & \\
\hline \multicolumn{9}{|l|}{ TP53 mutations } \\
\hline None detected & 1.00 & & & & 1.00 & & & \\
\hline TP53 mutation positive & $3.81(1.20-12.08)$ & 0.023 & & & $2.25(0.85-6.00)$ & 0.074 & & \\
\hline \multicolumn{9}{|l|}{ Sex } \\
\hline Female & 1.00 & & 1.00 & & 1.00 & & & \\
\hline Male & $3.45(1.54-6.25)$ & 0.003 & $3.07(1.30-7.19)$ & 0.010 & $2.25(0.85-6.00)$ & 0.105 & & \\
\hline \multicolumn{9}{|l|}{ T-classification } \\
\hline T1-2 & 1.00 & & & & 1.00 & & 1.00 & \\
\hline T3-4 & $1.44(0.68-3.03)$ & 0.341 & & & $4.52(1.48-13.73)$ & 0.008 & $4.03(1.29-12.66)$ & 0.017 \\
\hline \multicolumn{9}{|l|}{ N-classification } \\
\hline NO-2 & 1.00 & & & & 1.00 & & & \\
\hline N3-4 & 1.51 & 0.531 & & & $0.59(0.08-4.43)$ & 0.608 & & \\
\hline
\end{tabular}

and p16 - tumours. All patients with complete response had tumour p16 overexpression, whereas all patients with p16tumours were non-responders (Kim et al, 2013), suggesting that a full-dose chemotherapy regimen with a taxane and platinum in addition to a fluoropyrimidine might not be a valid approach for future studies in HPV - SCCAC. Concurrent 
administration of the anti-EGFR monoclonal antibody cetuximab with chemoradiotherapy has been explored as a radiosensitising strategy, but has been shown to confer high rates of severe toxicity, prohibiting its integration in chemoradiotherapy regimens (Deutsch et al, 2013; Olivatto et al, 2013). In an experimental study, a role for cetuximab as maintenance treatment following radiotherapy has been suggested (Milas et al., 2007).

\section{CONCLUSION}

This study shows that, in addition to established prognostic factors such as T-classification and sex, outcome of patients with SCCAC is strongly determined by tumour HPV/p16 status. Determination of HPV and p16 may be useful clinically to predict patients' responsiveness to standard treatment, and in the context of clinical studies investigating novel treatment strategies for anal cancer, it might be crucial to stratify patients based on HPV status. We show that in contrast to HPV + tumours, HPV - tumours frequently carry TP53 mutations, suggesting that there might be large differences in the genetics of HPV $+v s$ HPV - tumours. Studies investigating these molecular characteristics are now required to develop effective treatment strategies for patients with treatmentresistant SCCAC.

\section{ACKNOWLEDGEMENTS}

We thank Dr A Broeks and the Core Facility Molecular Pathology and Biobanking of the Netherlands Cancer Institute for their support with regard to the immunohistochemical analyses, I van Leeuwen for her support regarding the TP53 mutational analyses, and the referring Dutch hospitals who provided FFPE tumour tissue. No specific funding was used to finance this study.

\section{CONFLICT OF INTEREST}

The authors declare no conflict of interest.

\section{REFERENCES}

Agrawal N, Frederick MJ, Pickering CR, Bettegowda C, Chang K, Li RJ, Fakhry C, Xie T-X, Zhang J, Wang J, Zhang N, El-Naggar AK, Jasser SA, Weinstein JN, Treviño L, Drummond JA, Muzny DM, Wu Y, Wood LD, Hruban RH, Westra WH, Koch WM, Califano JA, Gibbs RA, Sidransky D, Vogelstein B, Velculescu VE, Papadopoulos N, Wheeler DA, Kinzler KW, Myers JN (2011) Exome sequencing of head and neck squamous cell carcinoma reveals inactivating mutations in NOTCH1. Science 333: $1154-1157$.

Ajani JA, Winter KA, Gunderson LL, Pedersen J, Benson AB, Thomas CR, Mayer RJ, Haddock MG, Rich TA, Willett CG (2010) Prognostic factors derived from a prospective database dictate clinical biology of anal cancer: the intergroup trial (RTOG 98-11). Cancer 116: 4007-4013.

Ang KK, Harris J, Wheeler R, Weber R, Rosenthal DI, Nguyen-Tân PF, Westra WH, Chung CH, Jordan RC, Lu C, Kim H, Axelrod R, Silverman CC, Redmond KP, Gillison ML (2010) Human papillomavirus and survival of patients with oropharyngeal cancer. N Engl J Med 363: 24-35.

Boyle JO, Hakim J, Koch W, van der Riet P, Hruban RH, Roa RA, Correo R, Eby YJ, Ruppert JM, Sidransky D (1993) The incidence of p53 mutations increases with progression of head and neck cancer. Cancer Res 53: 4477-4480.

Braakhuis BJM, Snijders PJF, Keune W-JH, CJLM Meijer, Ruijter-Schippers HJ, Leemans CR, Brakenhoff RH (2004) Genetic patterns in head and neck cancers that contain or lack transcriptionally active human papillomavirus. J Natl Cancer Inst 96: 998-1006.
Daling JR, Madeleine MM, Johnson LG, Schwartz SM, Shera KA, Wurscher MA, Carter JJ, Porter PL, Galloway DA, McDougall JK (2004) Human papillomavirus, smoking, and sexual practices in the etiology of anal cancer. Cancer 101: 270-280.

Deutsch E, Lemanski C, Pignon JP, Levy A, Delarochefordiere A, Martel-Lafay I, Rio E, Malka D, Conroy T, Miglianico L, Becouarn Y, Malekzadeh K, Paris E, Juzyna B, Ezra P, Azria D (2013) Unexpected toxicity of cetuximab combined with conventional chemoradiotherapy in patients with locally advanced anal cancer: results of the UNICANCER ACCORD 16 phase II trial. Ann Oncol 24: 2834-2838.

Gilbert DC, Williams A, Allan K, Stokoe J, Jackson T, Linsdall S, Bailey CM, Summers J (2013) p16(INK4A), p53, EGFR expression and KRAS mutation status in squamous cell cancers of the anus: Correlation with outcomes following chemo-radiotherapy. Radiother Oncol 109: $146-151$.

Harima Y, Sawada S, Nagata K, Sougawa M, Ohnishi T (2002) Human papilloma virus (HPV) DNA associated with prognosis of cervical cancer after radiotherapy. Int J Radiat Oncol Biol Phys 52: 1345-1351.

Hoots BE, Palefsky JM, Pimenta JM, Smith JS (2009) Human papillomavirus type distribution in anal cancer and anal intraepithelial lesions. Int J Cancer 124: 2375-2383.

James RD, Glynne-Jones R, Meadows HM, Cunningham D, Myint AS, Saunders MP, Maughan T, McDonald A, Essapen S, Leslie M, Falk S, Wilson C, Gollins S, Begum R, Ledermann J, Kadalayil L, Sebag-Montefiore D (2013) Mitomycin or cisplatin chemoradiation with or without maintenance chemotherapy for treatment of squamous-cell carcinoma of the anus (ACT II): a randomised, phase 3, open-label, $2 \times 2$ factorial trial. Lancet Oncol 14: 516-524.

Kato S, Han SY, Liu W, Otsuka K, Shibata H, Kanamaru R, Ishioka C (2003) Understanding the function-structure and function-mutation relationships of $\mathrm{p} 53$ tumor suppressor protein by high-resolution missense mutation analysis. Proc Natl Acad Sci USA 100(14): 8424-8429.

Kim S, Jary M, Mansi L, Benzidane B, Cazorla A, Demarchi M, Nguyen T, Kaliski A, Delabrousse E, Bonnetain F, Letondal P, Bosset JF, Valmary-Degano S, Borg C (2013) DCF (docetaxel, cisplatin and 5-fluorouracil) chemotherapy is a promising treatment for recurrent advanced squamous cell anal carcinoma. Ann Oncol 24(12): 3045-3050.

Kimple RJ, Smith MA, Blitzer GC, Torres AD, Martin JA, Yang RZ, Peet CR, Lorenz LD, Nickel KP, Klingelhutz AJ, Lambert PF, Harari PM (2013) Enhanced radiation sensitivity in HPV-positive head and neck cancer. Cancer Res 73: 4791-4800.

Kleter B, van Doorn LJ, Schrauwen L, Molijn A, Sastrowijoto S, ter Schegget J, Lindeman J, ter Harmsel B, Burger M, Quint W (1999) Development and clinical evaluation of a highly sensitive PCR-reverse hybridization line probe assay for detection and identification of anogenital human papillomavirus. J Clin Microbiol 37: 2508-2517.

Lampejo T, Kavanagh D, Clark J, Goldin R, Osborn M, Ziprin P, Cleator S (2010) Prognostic biomarkers in squamous cell carcinoma of the anus: a systematic review. Br J Cancer 103: 1858-1869.

Lechner M, Frampton GM, Fenton T, Feber A, Palmer G, Jay A, Pillay N, Forster M, Cronin MT, Lipson D, Miller Va, Brennan Ta, Henderson S, Vaz F, O’Flynn P, Kalavrezos N, Yelensky R, Beck S, Stephens PJ, Boshoff C (2013) Targeted next-generation sequencing of head and neck squamous cell carcinoma identifies novel genetic alterations in HPV + and HPV - tumors. Genome Med 5: 49.

Lu C, El-Deiry WS (2009) Targeting p53 for enhanced radio- and chemosensitivity. Apoptosis 14: 597-606.

Meulendijks D, Dewit L, Tomasoa NB, van Tinteren H, Beijnen JH, Schellens JHM, Cats A (2014) Chemoradiotherapy with capecitabine for locally advanced anal carcinoma: an alternative treatment option. Br J Cancer 111(9): 1726-1733.

Milas L, Fang F-M, Mason Ka, Valdecanas D, Hunter N, Koto M, Ang KK (2007) Importance of maintenance therapy in C225-induced enhancement of tumor control by fractionated radiation. Int J Radiat Oncol Biol Phys 67: $568-572$.

Nees M, Homann N, Discher H, Andl T, Enders C, Herold-Mende C, Schuhmann A, Bosch FX (1993) Expression of mutated p53 occurs in tumor-distant epithelia of head and neck cancer patients: a possible molecular basis for the development of multiple tumors. Cancer Res 53: 4189-4196.

Nelson RA, Levine AM, Bernstein L, Smith DD, Lai LL (2013) Changing patterns of anal canal carcinoma in the United States. J Clin Oncol 31: 1569-1575. 
Netherlands Cancer Registry. Available at: http://www.cijfersoverkanker.nl/ (last accessed 14 August 2013).

Olivatto LO, Vieira FM, Pereira BV, Victorino AP, Bezerra M, Araujo CM, Erlich F, Faroni L, Castro L, Lusis EC, Marins A, Ferreira CG (2013) Phase 1 study of cetuximab in combination with 5-fluorouracil, cisplatin, and radiotherapy in patients with locally advanced anal canal carcinoma. Cancer 119: 2973-2980.

Rietbergen MM, Snijders PJF, Beekzada D, Braakhuis BJM, Brink A, Heideman DAM, Hesselink AT, Witte BI, Bloemena E, Baatenburg-De Jong RJ, René Leemans C, Brakenhoff RH (2014) Molecular characterization of p16-immunopositive but HPV DNA-negative oropharyngeal carcinomas. Int J Cancer 134(10): 2366-2372.

Rödel F, Wieland U, Fraunholz I, Kitz J, Rave-Fränk M, Wolff Ha, Weiss C, Wirtz R, Balermpas P, Fokas E, Rödel C (2014) Human papillomavirus DNA load and p16(INK4a) expression predict for local control in patients with anal squamous cell carcinoma treated with chemoradiotherapy. Int J Cancer 136(2): 278-288.

Serup-Hansen E, Linnemann D, Skovrider-Ruminski W, Hogdall E, Geertsen PF, Havsteen H (2014) Human papillomavirus genotyping and p16 expression as prognostic factors for patients with american joint committee on cancer stages I to III carcinoma of the anal canal. J Clin Oncol 32(17): 1812-1817.

Skinner HD, Sandulache VC, Ow TJ, Meyn RE, Yordy JS, Beadle BM, Fitzgerald AL, Giri U, Ang KK, Myers JN (2012) TP53 disruptive mutations lead to head and neck cancer treatment failure through inhibition of radiation-induced senescence. Clin Cancer Res 18: 290-300.

Smeets SJ, Braakhuis BJM, Abbas S, Snijders PJF, Ylstra B, van de Wiel MA, Meijer GA, Leemans CR, Brakenhoff RH (2006) Genome-wide DNA copy number alterations in head and neck squamous cell carcinomas with or without oncogene-expressing human papillomavirus. Oncogene 25: $2558-2564$

Stengel A, Schnittger S, Weissmann S, Kuznia S, Kern W, Kohlmann A, Haferlach T, Haferlach C (2014) TP53 mutations occur in 15.7\% of ALL and are associated with MYC-rearrangement, low hypodiploidy and a poor prognosis. Blood 124: 251-258.

Stransky N, Egloff AM, Tward AD, Kostic AD, Cibulskis K, Sivachenko A, Kryukov GV, Lawrence MS, Sougnez C, McKenna A, Shefler E,
Ramos AH, Stojanov P, Carter SL, Voet D, Cortés ML, Auclair D, Berger MF, Saksena G, Guiducci C, Onofrio RC, Parkin M, Romkes M, Weissfeld JL, Seethala RR, Wang L, Rangel-Escareño C, Fernandez-Lopez JC, Hidalgo-Miranda A, Melendez-Zajgla J, Winckler W, Ardlie K, Gabriel SB, Meyerson M, Lander ES, Getz G, Golub TR, Garraway La, Grandis JR (2011) The mutational landscape of head and neck squamous cell carcinoma. Science 333: $1157-1160$.

Tandon S, Tudur-Smith C, Riley RD, Boyd MT, Jones TM (2010) A systematic review of p53 as a prognostic factor of survival in squamous cell carcinoma of the four main anatomical subsites of the head and neck. Cancer Epidemiol Biomarkers Prev 19: 574-587.

Valmary-Degano S, Jacquin E, Prétet J-L, Monnien F, Girardo B, Arbez-Gindre F, Joly M, Bosset J-F, Kantelip B, Mougin C (2013) Signature patterns of human papillomavirus type 16 in invasive anal carcinoma. Hum Pathol 44: 992-1002.

Westra WH, Taube JM, Poeta ML, Begum S, Sidransky D, Koch WM (2008) Inverse relationship between human papillomavirus-16 infection and disruptive p53 gene mutations in squamous cell carcinoma of the head and neck. Clin Cancer Res 14: 366-369.

Yemelyanova A, Vang R, Kshirsagar M, Lu D, Marks Ma, Shih IM, Kurman RJ (2011) Immunohistochemical staining patterns of p53 can serve as a surrogate marker for TP53 mutations in ovarian carcinoma: an immunohistochemical and nucleotide sequencing analysis. Mod Pathol 24: $1248-1253$.

Yhim H-Y, Lee N-R, Song E-K, Kwak J-Y, Lee ST, Kim JH, Kim J-S, Park HS, Chung I-J, Shim H-J, Hwang J-E, Kim HR, Nam T-K, Park M-R, Shim H, Park HS, Kim HS, Yim C-Y (2011) The prognostic significance of tumor human papillomavirus status for patients with anal squamous cell carcinoma treated with combined chemoradiotherapy. Int J Cancer 129: 1752-1760.

This work is published under the standard license to publish agreement. After 12 months the work will become freely available and the license terms will switch to a Creative Commons AttributionNonCommercial-Share Alike 4.0 Unported License.

Supplementary Information accompanies this paper on British Journal of Cancer website (http://www.nature.com/bjc) 